HIGHWAY TRAFFIC ANALYSIS AND DESIGN 


\title{
HIGHWAY TRAFFIC ANALYSIS AND DESIGN
}

\author{
R. J. Salter
}

Senior Lecturer in Civil Engineering University of Bradford 
() R. J. Salter 1974

Softcover reprint of the hardcover 1st edition 1974 978-0-333-15478-6

All rights reserved. No part of this publication may

be reproduced or transmitted, in any form or by

any means, without permission.

First published 1974 by

THE MACMILLAN PRESS LTD

London and Basingstoke

Associated companies in New York Dublin

Melbourne Johannesburg and Madras

SBN 333154789

ISBN 978-1-349-02095-9 ISBN 978-1-349-02093-5 (eBook)

DOI 10.1007/978-1-349-02093-5 


\section{Contents}

Preface

vii

\section{PART 1 TRAFFIC ANALYSIS AND PREDICTION}

1. Introduction to the transportation planning process 3

2. The transportation study area $\quad 8$

3. The collection of existing travel data 14

4. The external cordon and screenline surveys 18

5. Other surveys 22

6. Trip generation 25

7. Trip distribution 35

8. Modal split 53

9. Traffic assignment 64

10. The evaluation of transportation proposals 71

\section{PART 2 ANALYSIS AND DESIGN FOR HIGHWAY TRAFFIC}

11. The capacity of highways between intersections 95

12. Headway distributions in highway traffic flow 107

13. The relationship between speed, flow and density of a highway traffic
stream

14. The distribution of vehicular speeds in a highway traffic stream 135

15. The macroscopic determination of speed and flow of a highway traffic
stream

16. Intersections with priority control 150

17. Driver reactions at priority intersections $\quad 156$

18. Delays at priority intersections 163

19. A simulation approach to delay at priority intersections 171

20. Weaving action at intersections 182

21. Lengths of weaving sections calculated in accordance with the Highway Capacity Manual 189

22. Queueing processes in traffic flow 201

23. New forms of single level intersections 211

24. Grade-separated junctions 219

25. The environmental effects of highway traffic noise 229

26. The environmental effects of highway traffic pollution 245

27. Traffic congestion and restraint 250 


\section{PART 3 TRAFFIC SIGNAL CONTROL}

28. Introduction to traffic signals 269

29. Warrants for the use of traffic signals 271

$\begin{array}{ll}30 . & \text { Phasing } \\ 31 . & 275\end{array}$

31. Signal aspects and the intergreen period 278

32. Vehicle-actuated signal facilities $\quad 280$

33. The effect of roadway and environmental factors on the capacity of a
traffic-signal approach

34. The effect of traffic factors on the capacity of a traffic-signal approach $\quad 287$

35. Determination of the effective green time 291

36. Optimum cycle times for an intersection 294

37. The timing diagram 299

38. Early cut-off and late-start facilities 302

39. The effect of right-turning vehicles combined with straight-ahead and
left-turning vehicles

40. The ultimate capacity of the whole intersection 311

41. The optimisation of signal-approach dimensions 314

42. Optimum signal settings when saturation flow falls during the green
period

43. Delay at signal-controlled intersections 324

44. Determination of the optimum cycle from a consideration of delays on
the approach

45. Average queue lengths at the commencement of the green period 336

46. The co-ordination of traffic signals $\quad 342$

47. Time and distance diagrams for linked traffic signals 344

48. Platoon dispersion and the linking of traffic signals 349

49. The prediction of the dispersion of traffic platoons downstream of signals 352

50. The delay offset relationship and the linking of signals 354

51. Some area traffic control systems 363

$\begin{array}{ll}\text { Appendix } & 370\end{array}$

$\begin{array}{ll}\text { Index } & 373\end{array}$ 


\section{Preface}

More than a decade has passed since transport and traffic engineering first became recognised as an academic subject in centres of higher education in the United Kingdom. In this period the interdependence between land use and transport needs has been firmly established and the modelling of the transport system has seen considerable advances.

During this same time it has been realised that highway transport demand in urban areas will have to be balanced against the overall social, economic and environmental costs of movement.

This book includes the fundamental principles of land use, transport planning techniques and the subsequent economic evaluation of highway schemes. It reviews the analytical and practical aspects of highway traffic flow with sections discussing noise generation and pollution and the principles of congestion restraint and road pricing.

Highway intersections are considered in detail. There is a comprehensive treatment of traffic signal control, which ranges from isolated signal-controlled intersections to area-wide signal control.

So that many engineers and planners engaged in transport work, but without the benefits of formal tuition, will find this book useful, each section contains questions by which the reader may test his comprehension of the subject matter by reference to the model answers.

The author would like to express his thanks to those postgraduate students of transportation at the University of Bradford who made valuable comments on the script and examples; also to Professor C. B. Wilby, Chairman of the Schools of Civil and Structural Engineering, for his encouragement for transportation teaching and research.

The author would like to express his appreciation to the following bodies for permission to reproduce their copyright material: Bedfordshire County Council, the Department of the Environment, the Building Research Station, the Eno Foundation, Freeman Fox and Associates, the Greater London Council, Her Majesty's Stationery Office, the Institution of Civil Engineers, the Institution of Highway Engineers, National Research Council, Royal Borough of New Windsor, Traffic Engineering and Control, the Transport and Road Research Laboratory, and Wilbur Smith and Associates. 